\title{
O PROJECTO DO SENADOR HERCULANO DE FREITAS
}

Ao preclaro Autor do Projecto.

Tem ultimamente agitado o espirito publico o projecto do meu eminente mestre Dr. Herculano de Freitas, abolindo quaesquer peias ao exercicio do direito de perdão, que compete privativamente ao presidente de nosso Estado, pela letra da Constituição que nos rege.

Formou-se uma atmosphera de antipathia em torno do projecto, a pretexto de que é elle uma lei pessoal, facto que, de nenhum modo, se acha provado. Quando, porém, fosse verdadeira a accusação, dar-se-ia, no caso, o que denominam os juristas heterogeneidade de fim: propondose o legislador servir um individuo ou uma classe, tem sua lei em resultado uma vantagem para toda a communhão social.

E' phenomeno hoje muito conhecido, e de que se occupa Cruet, ao estudar o que elle denomina incidencia das leis, em sua obra sobre a Vida do Direito. Nosso proposito, pois, é só procurar provar que o projecto do notavej professor de Direito Constitucional, luminar das letras juridicas, cujas lições tive a dita de seguir, é o unico compativel com o texto de nossa Constituição e com os verdadeiros principios de Direito Publico.

Minha primeira these é esta: não pódem ser postas limitações ao exercicio do direito de perdão em face de nossa Constituição Estadual.

Facil é a demonstração, e, para a fazer, recorrerei a uma argumentação por absurdo, que parece irrespondivel. Si o decreto que se tenciona abrogar determinou que, só após o cumprimento da pena durante certo tempo, poderá o presidente perdoar, claro, evidente mesmo é que outro decreto poderá vir, dizendo que o presidente só terá facul- 
dade de perdoar quando o condemnado só tiver a cumprir cinco minutos do tempo da pena. Determinar um processo obrigatorio, é ainda tambem fraudar a Constituição. Supponhamos que prescreva a lei um processo que não possa ser ultimado senão dentro de um dilatado tempo: ficará, é claro, o presidente privado de perdoar antes de findo este termo, que póde comprehender uma grande parte do tempo da condemnação.

Isto é burlar a letra da Constituição, permittindo que o Congresso, por uma lei ordinaria, possa privar o presidente de verdadeiramente perdoar a pena, pois, em tal caso, o que ha é uma commutação apenas della, ou remissão parcial de seu cumprimento.

Sempre se fez esta distincção entre perdão e commutação, notando-se que a commutação não passa de uma graça parcial ou incompleta, na phrase de Braz Florentino.

A commutação era considerada como sendo uma parte do direito de perdoar, e a antiga Constituição do Imperio denominava este poder o de moderar as penas.

Em resumo, pois, qualquer restricção ao direito de perdoar que é concedido, com toda a amplitude, ao presidente de nosso Estado, desnatura este poder, é uma violação de nossa Constituição, ou uma fraude em sua interpretação. Si legem habemus, e lei fundamental, não é descabido mostrar quão salutar é ella, para que com amor seja cumprida, de boa mente seja applicada. O perdão é uma das medidas politicas de maior importancia. Seus salutares effeitos dependem, como os de todos os outros institutos politicos, da boa applicação, da discreção em seu uso. São os maiores pensadores que o dizem, é Montesquieu citado por Braz Florentino: "Executé avec sagesse, il peut avoir d'admirables effets." Varias são as funcções do perdão.

Citam, em primeiro logar, a necessidade de adaptar a lei penal ás circumstancias. A lei é rigida, sua applica- 
ção exige certo discernimento, e o perdão é um desses meios de adaptar as leis ás necessidades sociaes.

Pimenta Bueno e outros dizem que o perdão consegue "conciliar a lei com a equidade". Hoje, que tanto se fala em não haver crimes, mas criminosos, em livramento condicional, em pena arbitraria, hoje, que se condemna, em summa, a rigidez da lei penal, este motivo, apresentado por mestres constitucionalistas da estatura de Braz Florentino e Pimenta Bueno, é da maior importancia.

Ha um segundo motivo não menos digno de menção: é a possibilidade do erro nas condemnações, sem que possa a revisão soccorrer a tempo os condemnados. Basta imaginar a possibilidade de se haver tornado notorio que um condemnado é innocente, depois de esgottados os recursos, mesmo o de revisão, para se vêr que é indispensavel á perfeita distribuição da justiça o instituto do perdão.

Falam os mestres em expiação, em dar ao condemnado uma esperança, em necessidade de compaixão, quando o condemnado se mostra arrependido: na sciencia penal moderna, são razões de ordem inferior. 0 ponto que parece merecer algum desenvolvimento é o primeiro motivo, que modernamente deve tomar um outro aspecto. Cumpre que consideremos que o perdão é medida politica, destinada de algum modo a attrahir a sympathia ao chefe do Estado.

E' este que, quando vê condemnado um individuo que prestou serviços á Patria, tem o encargo de tomar em attenção taes serviços. E' elle que, sabendo que a pena, de algum modo, fere a familia do condemnado, póde tomar em consideração ser a de um condemnado a familia de um credor do Estado por serviços de importancia. Para o primeiro caso, basta lembrar o succedido com Lesseps: quão acertado seria, em tal hypothese, o perdão "que não silenciava a justiça, mas era exercido depois de ter ella preenchido sua missão" (Maugin). A amnistia é muito, $\epsilon \mathrm{m}$ taes circumstancias. Ainda mais, applical-a, quando se reconhece que ha crime, e não acto de patriotismo, por 
abuso denominado crime politico, é, de algum modo, tirar o valor que até hoje conservou. A pena, segundo a mais moderna concepção, deve ser applicada com o maximo da garantia social e o minimo do soffrimento individual.

Toda vez, pois, que o poder politico reconhecer que a sociedade nada soffrerá com o perdão, deverá delle usar como de uma faculdade que augmenta a força do chefe de Estado, gerando amor por elle entre os cidadãos. $A P o$ litica, no sentido scientifico do termo, traça os limites dentro dos quaes podem agir as normas juridicas. Fixar dentre os ideaes do Direito o que é possivel realizar, eis a funcção desta sciencia, segundo o notavel mestre Dr. Pedro Lessa. Pois bem! E' á Politica que cumpre dizer quando devem ser cumpridas as penas, ou quando devem os condemnados ser relevados de seu cumprimento.

Mas este meu artigo é particularmente destinado a resolver uma objecção que, por toda parte, ouço. Diz-se: o presidente póde abusar. Oh argumento filho da mais crassa ignorancia dos principios juridicos e sociaes!...

Ha meios de se cohibirem os abusos dos mais altos poderes da nação?

Como forçar o Presidente da Republica a bem proceder, a executar com lealdade as funcções do cargo?

Não quero dizer que as leis sejam inteiramente inefficazes, como pretende Cruet, mas em relação ás mais altas autoridades do Estado, póde-se receber por bom este asserto.

Não tratemos de pôr embaraços ridiculos á acção do presidente, mas busquemos ter para chefe de nosso Estado um homem incapaz de praticar actos contrarios ao interesse publico. $\mathrm{O}$ que se póde fazer é determinar, por um regulamento, quaes os meios de que devem lançar mão os condemnados para pedirem o perdão. Deve-se, porém, deixar sempre ao presidente a faculdade de dispensar todas as formalidades, todas as provas, todo processo, concedendo 
o perdão ex informata conscientia, segundo a expressão canonica.

Tudo quanto se está a dizer contra o projecto do meu sabio mestre não passa de argumentação cerebrina, jurisprudencia de gabinete; como dizia Ihering, ou quiçá de igrejinha politica, tomando agora o termo no sentido vulgar de arte de achar que sempre os nossos têm razão, e: que o adversario defende a má causa.

S. Paulo, Setembro, 1916.

Braz de Sousa Arruda,

Docente da Faculdade. 